\title{
Pengaruh Peran Guru Terhadap Kualitas Guru Sebagai Pelayan Anak Sekolah Minggu Di Gereja Makassar City Blessing
}

\author{
Citra Yustina Siregar, Tri Supartini
}

\begin{abstract}
Abstrak
Tujuan penulisan ini untuk mengetahui sejauh mana Pengaruh Peran Guru Terhadap Kualitas Guru Sebagai Pelayan Anak di Gereja Makassar City Blessing. Peranan artinya sesuatu yang menjadi bagian atau yang memegang pimpinan yang terutama, dalam terjadinya suatu hal atau peristiwa. Peranan adalah melaksanakan panggilan dan tugas yang memiliki misi untuk diemban, dan dalam rangka melaksanakan suatu tugas. Metode yang digunakan adalah metode kualitatif. Dari pengertian diatas dapat dirangkumkan bahwa peranan adalah suatu bagian yang memegang pimpinan dalam suatu perkumpulan atau peristiwa. Dalam hal peranan, seseorang dapat memengaruhi dan mengarahkan orang lain kepada suatu tujuan berdasarkan misi yang diemban. Guru memiliki peran yang sangat penting dalam pembelajaran, peserta didik memerlukan peran seorang guru untuk membantunya dalam proses perkembangan diri dan mengoptimalkan bakat dan kemampuan yang dimiliki peserta didik. Tanpa peran seorang guru, mustahil peserta didik dapat mewujudkan tujuan hidupnya secara optimal. Sebagai orang Kristen, guru hendaknya guru mengembangkan dan memahami tugas pelayanan mengajar yang selalu berakar pada iman Kristen. Iman Kristen itu bersumber pada kebenaran dan prinsip-prinsip firman Tuhan sebagaimana yang diungkapkan oleh Alkitab, sehingga dalam tugas pelayanan mengajar guru mampu berpikir dan bertindak dalam terang iman. Menyadari pentingnya peranan guru yang berkualitas dalam pelayanannya maka kualitas guru Sekolah Minggu mencakup beberapa faktor yaitu iman Kristen, profesionalisme guru dan pandangan hidup guru itu sendiri.
\end{abstract}

Kata-kata kunci: Peran, Kualitas, Guru dan Anak.

\section{Pendahuluan}

\section{Latar Belakang Masalah}

Perkembangan dunia saat ini menawarkan berbagai macam pilihan kepada anakanak. Media menawarkan berbagai macam tontonan yang menarik untuk dilihat, mulai dari film kartun yang menawarkan mimpi sampai yang berwujud kekerasan. Tak jarang juga anak-anak menikmati tontonan yang tidak ditujukan untuk segmen usia mereka seperti sinetron ataupun film dan acara televisi untuk orang dewasa. Di sisi lain, anak-anak juga ditawarkan berbagai jenis permainan, mulai dari permainan ala Time zone sampai permainan 
dengan konsep second life di mana mereka bisa menjadi orang lain dan dapat mengatur dan menata kehidupan mereka sendiri. ${ }^{1}$

Dalam hal ini gereja harus siap menghadapi segala tantangan yang ada dengan meningkatkan mutu pelayanan dalam kehidupan jemaat. George Barna seorang tokoh pertumbuhan gereja mengatakan:

Gereja itu berada ditengah-tengah lingkungan yang sedang bersaing. Gereja setempat bersaing dengan organisasi-organisasi lain untuk merebut waktu, perhatian, uang, kesetiaan, dan singkatannya menarik hati orang banyak. Persaingannya yang sesungguhnya bukanlah gereja melainkan organisas i, kesempatan dan filsafat lain yang dapat menjadi alternatif untuk kehidupan Kristen. Saingan utama itu datangnya dari siaran radio, film, tempat-tempat hiburan, klub-klub olahraga dan lain-lain. ${ }^{2}$

Dengan demikian sudah seharusnya gereja perlu menyadari dan memikirkan bagaimana caranya gereja dapat memenuhi kebutuhan anggotanya dalam hal ini salah satunya anak-anak sekolah minggu.Sekolah minggu adalah sarana penginjilan yang terbesar bagi gereja. Maka sebagai sebuah sarana penginjilan terbesar bagi gereja, guru-guru sekolah minggu memegang peranan besar dalam proses belajar mengajar di sekolah minggu.

Memang tak dapat dipungkiri bahwa saat ini pelayanan guru Sekolah Minggu sedang diperhadapkan dengan tantangan yang sangat kompleks. Tidak sedikit guru-guru sekolah minggu mengeluh karena mengalami krisis murid Sekolah Minggu yang telah asuh sekian lama. Di satu sisi acara sekolah minggu pun harus bersaing keras dengan dunia hiburan anakanak masa kini, baik yang ditayangkan melalui TV maupun lewat berbagai media yang tersedia dengan para tokohnya yang sangat memikat hati anak-anak. Dalam hal ini, guru sekolah minggu dituntut mengajarkan Alkitab secara kreatif, mengupayakan agar setiap acara sekolah minggu selalu menarik. Dengan demikian, sekolah minggu menjadi acara yang dinamis, kreatif dan sesuai dengan dunia anak masa kini. ${ }^{3}$ Dengan kata lain para guru sekolah minggu diharapkan dapat membangun sebuah sekolah minggu yang maju dan berkembang, baik dalam segi kualitas maupun kuantitas.

Mengajar anak-anak memang tidak mudah, guru harus mengenal gaya belajar anak agar dapat menemukan apa yang menjadi masalah anak di dalam belajar. Apabila guru tidak kreatif dalam mengajar, maka yang terjadi adalah anak akan merasa bosan, malas, jenuh, dan tidak suka mendengarkan firman Tuhan. Apalagi anak-anak sekarang semakin sibuk dengan sekolah, kursus-kursus, dan berbagai kesibukan lainnya, sehingga kegiatan mereka padat sekali. Bisa dibayangkan, jika acara sekolah minggu tidak menarik, mereka mungkin bisa saja merasa "rugi" untuk hadir di sekolah minggu. Jika ini yang terjadi, apa yang bakal terjadi kepada mereka, sementara anak-anak adalah harapan dan generasi masa depan gereja.

Mary Go Setiawani mengatakan "Anak-anak adalah harapan bagi masa yang akan

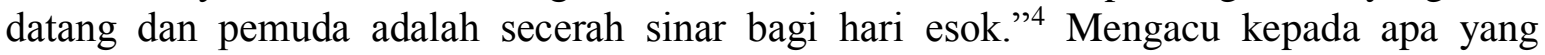
dikatakan Mary Go Setiawani maka tidak dapat dipungkiri betapa pentingnya dan

\footnotetext{
${ }^{1}$ Magdalena, "Faktor-faktor Yang Mempengaruhi Kinerja Guru Sekolah Minggu Komisi Anak Gereja Kristen Indonesia Gunung Sahari,”( Tesis M.Si., Univesitas Indonesia, 2010), 1, diakses 7 Agustus 2017, http://lib.ui.ac.id/file?file=digital/136187-T\%2028139-Faktor-faktor\%20yang-full\%20text.pdf.

${ }^{2}$ George Barna, Memasarkan Gereja (Bandung: Kalam Hidup, 1988), 18.

${ }^{3}$ Paulus Lie, Mengajar Sekolah Minggu yang Kreatif (Jogjakarta: ANDI, 1997), 1.

${ }^{4}$ Mary Go Setiawani, Pembaruan Mengajar (Bandung: Kalam Hidup, 1990), 8.
} 
berharganya anak-anak. Mengapa anak-anak? Masa kanak-kanak adalah masa untuk menanamkan pengalaman-pengalaman yang dasar dengan Allah. Banyak di antara anak-anak yang senang dengan keadaan gurunya yang baik, kreatif, menarik, terampil dan tidak monoton. Namun rata-rata guru sekolah minggu kurang mengenal anaknya baik dari segi rohaninya maupun dari segi jasmaninya. Guru pun kurang menunjukkan metode-metode yang baik serta model guru yang kreatif, sehingga anak-anak tidak tertarik dan tidak memiliki semangat untuk mendengarkan firman Tuhan yang disampaikan.

Dalam hal ini peran dan kualitas guru sangat memegang peranan penting dalam proses belajar mengajar seperti pendapat Earl V. Pullias dan James D. Young, yang dikutip Sidjabat, "Guru adalah segala-galanya", artinya banyak segi dari kedudukan dan peranan guru dalam membentuk, membimbing, dan memperlengkapi anak didik. ${ }^{5}$

Dengan melihat fakta yang terjadi di dalam pelayanan sekolah minggu Gereja Makassar City Blessing, guru kurang memperhatikan kondisi yang terjadi dengan anak-anak sekolah minggu. Ada begitu banyak kendala yang terjadi, baik karena kondisi ruangan yang kurang memadai, dan perbedaan durasi ibadah sekolah minggu dengan ibadah raya kecenderungan ibadah sekolah minggu lebih daahulu selesai dibandingkan dengan ibadah raya sehingga anak-anak harus menunggu , kurangnya kunjungan kepada anak-anak, kurangnya bahan ajar.

\section{Pokok Masalah}

Berdasarkan pada latar belakang masalah yang disebut diatas, maka untuk memfokuskan pokok pembahasan, maka dibuatlah pokok masalah yaitu sejauh mana pengaruh peran guru terhadap kualitas pelayanan anak.

\section{Tujuan Penelitian}

Adapun yang menjadi tujuan karya ilmiah ini ialah untuk mengetahui Pengaruh Peran Guru Terhadap Kualitas Guru Sebagai Pelayan Anak Sekolah Minggu di Gereja Makassar City Blessing.

\section{Manfaat Penelitian}

Dengan tercapainya tujuan penelitian di atas maka manfaat yang diharapkan dalam penulisan skripsi ini adalah:

Pertama, dapat menjadi masukan dan memberi manfaat bagi penulis dalam kehidupan dan juga pelayanan penulis sendiri.

Kedua, dapat menjadi masukan kepada guru-guru sekolah minggu supaya dapat meningkatkan kualiatas pengajaran di sekolah minggu.

Ketiga, salah satu syarat untuk memperoleh gelar sarjana (SI) pada Konsentrasi Pendidikan Agama Kristen di Sekolah Tinggi Theologia Jaffray Makassar.

${ }^{5}$ B. S Sidjabat, Menjadi Guru Profesional (Bandung: Kalam Hidup, 2000), 31; Earl V. Pullias dan James D. Young, Guru Dalam Pengabdian (Tarate,1979 ), 27. 


\section{Metode Penelitian}

Metode penelitian yang penulis gunakan di dalam penyusunan skripsi ini yaitu kualitatif dengan teknik pengumpulan data;

Pertama, penulis melakukan kajian pustaka, yaitu dengan pengumpulan data melalui buku dan internet yang berhubungan dengan buku-buku dan internet yang berhubungan dengan pelayanan sekolah minggu.

Kedua, penulis mengadakan observasi langsung di lapangan, yaitu dengan cara membagikan angket yang disebarkan kepada anak sekolah minggu dengan tujuan untuk mendapatkan data yang akurat tentang sejauh mana pengaruh peran guru terhadap kualitas pelayanan sekolah minggu.

Ketiga, penulis mengadakan wawancara kepada objek kajian (pembina guru sekolah minggu), wawancara dilakukan untuk menguatkan data angket, dan untuk mendapatkan data yang lebih mendalam tentang pengaruh peran guru sekolah minggu terhadap kualiatas pelayanan sekolah minggu.

\section{Batasan Penelitian}

Ruang lingkup penelitian karya ilmiah ini adalah berkisar Peran Guru Terhadap Kualitas Guru Sebagai Pelayan Anak Sekolah Minggu di Gereja Makassar City Blessing

\section{Kesimpulan}

Berdasarkan penelitian dari bab sebelumnya maka pengaruh peran guru di Gereja Makassar City Blessing sebagai pendoa dan penginjil sudah cukup baik. Sedangkan peran guru sebagai pengajar, gembala dan konselor belum baik dan perlu ditingkatkan. Dengan demikian peran guru di Gereja Makassar City Blesing belum maksimal dalam menjalankan perannya sebagai guru sekolah Minggu. Dalam kualitas guru sekolah minggu di Gereja Makassar City Blessing dalam profesionalisme dan iman kristen sudah baik, tetapi dalam keteladanan belum baik untuk sangat perlu guru sekolah minggu lebih lagi membangun hubungan yang benar dengan Tuhan supaya guru sekolah minggu dapat mengendalikan perkataannya dengan baik.

\section{Kepustakaan}

Abineno, J. L. Ch. Doa Menurut Kesaksian Perjanjian Baru. Jakarta: BPK Gunung Mulia, 1992.

Anderson, Marvis.L. Pola Mengajar Sekolah Minggu. Bandung: Kalam Hidup, 2000.

Astika, Made, DAN Bunga, Selvianty. "Hubungan Kompetensi Sosial Guru Kristen Terhadap Perkembangan Karakter Siswa: Tantangan Pendidikan Kristen Dalam Mencerdaskan Youth Generation" Jurnal Jaffray [Online], Volume 14 Nomor 1 (10 Maret 2016).

Berkhof, Louis. Teologi Sistematika 4 Doktrin Keselamatan. Jakarta: Lembaga Reformed Injili Indonesia, 1997.

Biehl, Bobb dan James W. Hagelganz. Berdoa. Bandung: Kalam Hidup, 1976.

Collins, Gary R. Konseling Kristen Yang Efektif. Malang: Literatur SAAT, 2007. 
Daun, Paulus. Menuntun Ke Dalam Pelayanan Sekolah Minggu. Ujung Pandang: Medio,1984.

Doherty, Sam. Mengapa Menginjili Anak-anak. Jakarta: Lembaga Penginjilan Anak-anak Indonesia, 2000.

Dresslhaus, Richard L. Penginjilan di Sekolah Minggu. Malang: Gandum Mas, 2003.

Gultom, Andar. Profesional, Standar Kompetensi, Dan Pengembangan Profesi Guru PAK. Bandung: Bina Media Informasi, 2007.

Harry, M. Perkembangan Gereja dan Penginjilan Melalui Sekolah Minggu. Bandung: Lembaga Literatur Baptis, 1984.

Hartman, Doug dan Doug Shuterland. Pedoman Pemuridan. Bandung: Kalam Hidup, 2009. Heath, W. Stanley. Teologi Pendidikan Anak. Bandung: Yayasan Kalam Hidup, 2005.

Homrighausen, E. G, I. H Enklaar. Pendidikan Agama Kristen. Jakarta: BPK Gunung Mulia, 2011.

Kristianto, Paulus Lilik. Prinsip dan Praktik Pendidikan Agama Kristen. Yogyakarta: Andi, 2006.

Laufer, Ruth. Pedoman Pelayanan Anak. Surabaya: Bahtera Grafika, 1997.

Leister, Anderew D. Pelayanan Pastoral Bersama Anak-anak Dalam Krisis. Malang: Seminari Alkitab Asia Tenggara, Departemen Literatur Saat, 2003.

Lewis, Lelia. Mengajar untuk Mengubah Kehidupan. Bandung: Yayasan Kalam Hidup, 2001.

Lie, Paulus. Tehnik Kreatif dan Terpadu Dalam Mengajar Sekolah Minggu. Yogyakarta: Andi, 2006.

Martin dan Diedre, Bobgan. Bimbingan Berdasarkan Firman Allah. Bandung: Kalam Hidup, 1985.

Murray, Robert. Berjaga-jaga Dalam Doa. Surabaya: Momentum, 2013.

Nainggolan, John. M. Guru Agama Kristen Sebagai Panggilan Dan Profesi. Bandung: Bina Media Informasi, 2010.

Nasution, S. Didaktik Asas-Asas Mengajar. Bandung: Jemmars, 1982.

Non-Serrano, Jansen Belandina. Profesionalisme Guru dan Bingkai Materi. Bandung: Bina Media Informasi, 2005.

Nuhamara, Daniel. "Pengutamaan Dimensi Karakter Dalam Pendidikan Agama

Kristen" Jurnal Jaffray [Online], Volume 16 Nomor 1 (19 Maret 2018)

Piland, Harry M. Perkembangan Gereja dan Penginjilan Melalui Sekolah Minggu. Bandung: Lembaga Literatur Baptis, 1984.

Ranon, Ayub. Kepemimpinan Kharismatis. Jakarta: Gunung Mulia, 2006.

Riggs, Ralph M. Gembala Sidang Yang Berhasil. Malang: Gandum Mas, 2003.

Setiawani, Mary Go. Menerobos Dunia Anak. Bandung: Kalam Hidup, 2000.

Sidjabat, B. S. Menjadi Guru Profesional. Bandung: Yayasan Kalam Hidup, 2000.

Sitompul, A. A. Di Pintu Gerbang Pembinaan Warga Gereja. Jakarta: BPK Gunung Mulia,1997.

Sulistyono, Edy. Anak-anak Sasaran Strategis Bidikan Iblis. Yogyakarta: ANDI, 2009.

Tong, Stephen. Arsitek Jiwa. Jakarta: Lembaga Reformed Injil Indonesia, 1993. Membesarkan Anak-anak Dalam Tuhan. Jakarta: Lembaga Reformed Injil Indonesia, 1994.

Tripp, Lane dan Paul Trip. Bagaimana Orang Berubah. Surabaya: Momentum, 2013. 
Tuhumury, Nelly. Filsafat Pendididikan Kristen. Makassar: Diktat Sekolah Tinggi Theologia Jaffray, 1986. Belum dipublikasikan.

Uno, Hamzah B. Profesi Keguruan. Jakarta: Bumi Aksara, 2008.

Vretze, Th. C. Agama Israel Kuno. Malang: Gandum Mas, 1981.

Wijarnoko, Mendidik Anak. Jakarta: Suara Pemulihan, 2003.

Wijaya, Hengki (ed.). Metodologi Penelitian Pendidikan Teologi. Makassar: Sekolah Tinggi Theologia Jaffray, 2016.

Yahya, Ayub. Menjadi Guru Sekolah Minggu Yang Efektif. Yogyakarta: Foot Print, 2011. 